\title{
CORRECTION
}

\section{Correction to: Tyrosine-hydroxylase immunoreactivity in the mouse transparent brain and adrenal glands}

\author{
David Godefroy $^{1,2} \cdot$ William Rostène ${ }^{1}\left[\right.$ ] $\cdot$ Youssef Anouar $^{2} \cdot$ Annabelle Reaux-Le Goazigo $^{1}(\mathbb{C}$
}

Published online: 17 November 2018

(c) Springer-Verlag GmbH Austria, part of Springer Nature 2018

\section{Correction to: Journal of Neural Transmission \\ https://doi.org/10.1007/s00702-018-1925-x}

Unfortunately, the given name and family name of the fourth author was incorrectly tagged in the xml data, therefore it is abbreviated wrongly as "Goazigo AR" in Pubmed. The correct given name is Annabelle and family name is Reaux-Le Goazigo.

The original article can be found online at https://doi.org/10.1007/ s00702-018-1925-x.

William Rostène

william.rostene@inserm.fr

1 Institut de la Vision, Sorbonne Université, INSERM CNRS

UMRS 968, Paris, France

2 Normandie Université, INSERM, U1239, DC2N, IRIB,

UNIROUEN, Mont-St-Aignan, France 